Strelbytska I., Hudyma A. Dynamics of violations the absorption function of the small intestine in conditions of acute blood loss complicated by ischemia-reperfusion of the limbs and their correction. Journal of Education, Health and Sport. 2021;11(1): 351-360. eISSN 2391-8306. DOI http://dx.doi.org/10.12775/JEHS.2021.11.1.035

https://apcz.umk.pl/czasopisma/index.php/JEHS/article/view/JEHS.2021.11.1.035

https://zenodo.org/record/5156115

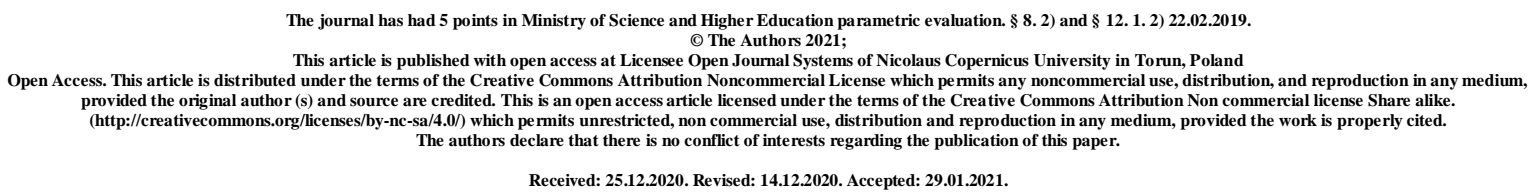

UDK 616.341-008.6:616.748-005.1/-005.4]-085-092.9

\title{
DYNAMICS OF VIOLATIONS THE ABSORPTION FUNCTION OF THE SMALL INTESTINE IN CONDITIONS OF ACUTE BLOOD LOSS COMPLICATED BY ISCHEMIA-REPERFUSION OF THE LIMBS AND THEIR CORRECTION
}

\author{
I. V. Strelbytska, A. A. Hudyma \\ Ivan Horbachevsky Ternopil National Medical University \\ Ministry of Health of Ukraine
}

\begin{abstract}
Introduction. In the structure of modern injuries in wartime and peacetime the share of gunshot wounds increased significantly. The timeliness of applying a tourniquet is one of the main methods of saving lives on the battlefield. The patterns of formation of enteral insufficiency syndrome in conditions of acute blood loss complicated by ischemia-reperfusion of the limb have not been studied enough. There are no data on the features of violations of the absorption function of the small intestine in these conditions and the effectiveness of correction with Carbacetam, which is able to reduce the manifestations of acute hemic hypoxia and ischemic-reperfusion syndrome.

The objective of research: To establish the peculiarities of the absorption function of the small intestine in the pathogenesis of acute blood loss, ischemia-reperfusion of the limb and their combination. To evaluate the effectiveness of Carbacetam in the correction of identified abnormalities.
\end{abstract}

Materials and methods. The experimental studies were conducted on 108 white 
nonlinear male rats weighing 200-220 g, which were housed in standard vivarium conditions. All animals were divided into five groups: control and four experimental. Under thiopentalsodium anesthesia in the first experimental group was simulated ischemia-reperfusion of the limb, in the second group - acute blood loss, and in the third group - these injuries were combined. In the fourth experimental group, animals with acute blood loss and ischemiareperfusion of the limb were intraperitoneally administered Carbacetam at a dose of $5 \mathrm{mg}$ per kilogram of animal weight. After 1 and 2 hours, as well as after 1, 7 and 14 days studied the absorption function of the intestines by D-xylose test.

The results and discussion. Simulation of limb ischemia-reperfusion compared with the control group causes a decrease in the content of D-xylose in the urine after 1 day of the reperfusion period. Also, acute blood loss is accompanied by a significant decrease in this indicator after 1 day. Until the end of the experiment the rate increases, but up to 14 days does not reach the level of control. The combination of acute blood loss and ischemia-reperfusion of the limb causes a decrease in the content of D-xylose in the urine starting from 1 hour of the experiment, which reaches a minimum after 1 day and remains at the same level until 14 days. In these terms the rate was the lowest compared to other studied groups. The use of Carbacetam for corrective purposes in rats with acute blood loss complicated by ischemiareperfusion of the limb, compared with animals without correction significantly reduces the detected abnormalities after 7 days and more after 14 days of use.

Conclusions. Complications of acute blood loss by ischemia-reperfusion of the limb causes a significant decrease in the absorption function of the small intestine after 1 day of the experiment. The intensity of disorders was significantly higher compared to other experimental groups. The use of Carbacetam for 7-14 days in the reperfusion period in animals with acute blood loss complicated by limb ischemia-reperfusion, compared with animals without correction, causes a significant increase in the absorption function of the small intestine. This indicates the protective effect of the drug under the conditions of simulated pathology.

Key words: small intestine; blood loss; ischemia-reperfusion of the limb; antioxidant-absorption function; Carbacetam.

Introduction. In the structure of modern injuries in wartime and peacetime the share of gunshot wounds increased significantly. More than $60 \%$ of cases are lesions of the extremities, which are accompanied by massive external blood loss. 
The timeliness of first aid, especially the timeliness of applying a tourniquet is one of the main methods of saving lives on the battlefield [1, 2]. The safe period of complete ischemia of the limb is two hours.

According to some authors, acute limb ischemia during two hours and, especially, revascularization lead to the formation of active forms of oxygen, development of metabolic disorders, activation of lipid peroxidation processes, cell membrane damage with the release of endogenous toxins into the systemic bloodstream. The toxins deepen under conditions of acute blood loss and initiate systemic disorders in tissues and organs remote from the site of direct lesion [3, 4, 5]. The development of metabolic and functional disorders under conditions of acute blood loss complicated by ischemia-reperfusion of the limb in the liver, kidneys and lungs has been proved $[6,7,8]$.

It is known that the leading role in the pathogenesis of the syndrome of endogenous intoxication and multiorgan failure belongs to the gastrointestinal tract. In the gastrointestinal tract under conditions of acute blood loss appear disorders due to the centralization of hemodynamics, disorders of microcirculation in the intestinal wall, hypoxic and reperfusion damage of enterocytes, the action of pro-inflammatory mediators, edema of the intestinal wall $[9,10]$.

In these conditions, arises a syndrome of enteral insufficiency, that manifested by violation of motor-evacuatory, barrier, secretory and absorption functions of the intestines, as well as parietal and intraluminal digestion [11]. Due to the translocation of the microflora and the mass entry into the bloodstream of a microbial toxin - lipopolysaccharide, another "false" pathological circle closes, which triggers a cascade of reactions that accelerates the development of multiorgan failure.

However, the patterns of formation of enteral insufficiency syndrome in conditions of acute blood loss complicated by ischemia-reperfusion of the limb have not been studied enough. There are no data on the features of violations of the absorption function of the small intestine in these conditions and the effectiveness of correction with Carbacetam, which is able to reduce the manifestations of acute hemic hypoxia and ischemic-reperfusion syndrome [12].

The objective of research: To establish the peculiarities of the absorption function of the small intestine in the pathogenesis of acute blood loss, ischemia-reperfusion of the limb and their combination. To evaluate the effectiveness of Carbacetam in the correction of identified abnormalities. 
Materials and methods. In the experiments used 108 nonlinear males rats weighing 200-220 g. All animals were divided into five groups: control and four experimental (6 animals in each groups).

All experiments were performed under thiopental sodium anesthesia $\left(40 \mathrm{mg} \mathrm{kg}^{-1}\right.$ body weight ) dosed. In the first experimental group were simulated ischemia-reperfusion of the limb. For this purpose, a strip of elastic tourniquet "SWAT-T" (USA) width of $10 \mathrm{~mm}$ was proximally applied to the left foot, which completely stopped the blood flow for 120 minutes. In the second experimental group, acute blood loss (20\% of the circulating blood volume) was simulated by crossing the femoral vein. In the third experimental group, these injuries were combined. In the fourth experimental group, animals with acute blood loss and ischemia-reperfusion of the limb intraperitoneally administered Carbacetam, for corrective purposes. Administered at a dose of $5 \mathrm{mg}$ per kilogram of animal weight (L.M. Litvinenko Institute of Physical-Organic Chemistry and Coal Chemistry of the National Academy of Sciences of Ukraine, Kyiv) [6]. In the control group, the animals were only anesthetized using an equivalent dose of sodium thiopental. After 1 and 2 hours, as well as after 1, 7 and 14 days under conditions of thiopental sodium anesthesia in experimental animals studied the absorption function of the intestine by D-xylose test. D-xylose is a chemically inert carbohydrate that is absorbed by passive diffusion, is not metabolized in the human body, excreted in the urine and adequately reflects the absorption function of the small intestine [13]. Experimental animals were intragastrically injected with $10 \%$ solution of D-xylose at the rate of $100 \mathrm{mg} \cdot \mathrm{kg}^{-1}$ body weight. Next, were collected urine during the 4 hours. The concentration of D-xylose was determined [14]. The test animals were subsequently euthanized through complete exsanguination from the heart.

All experimental procedures fulfilled the international standards for the humane treatment of animals in compliance with the regulations of «The European Convention for the protection of vertebrate animals used for experimental and other scientific purposes (European Convention, 1986)».

All obtained data were processed to the statistical analysis by the nonparametric The Mann-Whitney U test using STATISTICA 10.0 software («StatSoft Inc.», USA).

The results and discussion. As we can seen from table.1, under conditions of ischemia-reperfusion of the limbs the content of D-xylose in the urine compared with the control group decreased, however, the result was statistically significant after 1 day of the reperfusion period $(20.1 \%, \mathrm{p}<0.05)$. 
Table 1 - Dynamics of D-xylose content $\left(\mathrm{mg} \cdot \mathrm{ml}^{-1}\right)$ in urine after acute blood loss complicated by ischemia-reperfusion of the limb (Me (LQ; UQ) - median (lower and upper quartiles))

\begin{tabular}{|c|c|c|c|c|c|}
\hline \multirow{2}{*}{$\begin{array}{l}\text { Experimental } \\
\text { group }\end{array}$} & \multicolumn{5}{|c|}{ The term of the reperfusion period } \\
\hline & $1 \mathrm{~h}$ & $2 \mathrm{~h}$ & 1 day & 7 days & 14 days \\
\hline \multicolumn{6}{|c|}{ Control $=51,70(46,25 ; 57,75)(\mathrm{n}=6)$} \\
\hline \multirow{4}{*}{$\begin{array}{l}\text { Experimental group } 1 \\
\text { Ischemia-reperfusion }\end{array}$} & 50,50 & 48,50 & $41,30^{*}$ & $46,40^{1 \text { д }}$ & $51,40^{1 \text { д }}$ \\
\hline & 47,35 & 44,60 & 37,35 & 45,60 & 49,25 \\
\hline & 54,25 & 51,65 & 44,65 & 50,05 & 52,35 \\
\hline & $(n=6)$ & $(n=6)$ & $(n=6)$ & $(n=6)$ & $(\mathrm{n}=6)$ \\
\hline \multirow{4}{*}{$\begin{array}{l}\text { Experimental group } 2 \\
\text { Blood loss }\end{array}$} & 44,50 & 41,20 & $34,20^{* 1 \Gamma}$ & $38,40^{*} 1 \Gamma$ & $42,40^{* 1 д}$ \\
\hline & 42,40 & 37,60 & 30,45 & 37,75 & 41,00; \\
\hline & 51,25 & 46,60 & 38,10 & 41,45 & 45,45 \\
\hline & $(n=6)$ & $(n=6)$ & $(\mathrm{n}=6)$ & $(n=6)$ & $(n=6)$ \\
\hline \multirow{4}{*}{$\begin{array}{l}\text { Experimental group } 3 \\
\text { Ischemia-reperfusion } \\
+ \text { blood loss }\end{array}$} & $42,90^{*}$ & $32,30^{* 1 \Gamma}$ & $22,90^{* 1 \Gamma, 2 \Gamma}$ & $26,60^{* 1 \Gamma, 2 \Gamma}$ & $28,90^{* 1 \Gamma, 2 \Gamma}$ \\
\hline & 42,25 & 30,85 & 20,85 & 23,70 & 25,60 \\
\hline & 45,50 & 35,70 & 24,35 & 28,00 & 29,95 \\
\hline & $(n=6)$ & $(n=6)$ & $(n=6)$ & $(n=6)$ & $(n=6)$ \\
\hline $\mathrm{p}_{1-2}$ & $>0,05$ & $>0,05$ & $>0,05$ & $<0,05$ & $<0,05$ \\
\hline $\mathrm{p}_{1-3}$ & $<0,05$ & $<0,05$ & $<0,05$ & $<0,05$ & $<0,05$ \\
\hline $\mathrm{p}_{2-3}$ & $>0,05$ & $<0,05$ & $<0,05$ & $<0,05$ & $<0,05$ \\
\hline
\end{tabular}

Notes.

1. ${ }^{*}$ - differences relative to the control group are statistically significant $(\mathrm{p}<0.05)$;

2. $\mathrm{p}_{1-2}$ - the probability of differences between experimental groups 1 and 2 ;

3. $\mathrm{p}_{1-3}$ - the probability of differences between experimental groups 1 and 3;

4. $\mathrm{p}_{2-3}$ - the probability of differences between experimental groups 2 and 3 .

Simulation of acute blood loss also caused a decrease in the content of D-xylose in the urine. The result was statistically significant compared with the control after 1, 7 and 14 days (33.8, 25.7 and 18.0\%, p<0.05). After 1 and 7 days of the experiment, the indicator was also significantly lower than after 1 hour (on 23.1 and $13.7 \%$, p<0.05). After 14 days, the rate increased and became $24.0 \%$ higher than after 1 day of the experiment $(\mathrm{p}<0.05)$.

Complications of acute blood loss by ischemia-reperfusion of the limb led to a decrease in the content of D-xylose compared with the control after 1 hour of the experiment (by $17.0 \%, \mathrm{p}<0,05)$. Then the rate decreased and reached a minimum after 1 day of the experiment (by $55.7 \%, \mathrm{p}<0.05$ compared with the control), that was also significantly less than after 1 hour and 2 hours, respectively, at 46.6 and 29, $1 \%, p<0.05)$. It is noteworthy that at the same level the content of D-xylose in the urine remained until the 14th day of the experiment $(\mathrm{p}>0.05)$. 
Comparison of the experimental groups showed that after 1 hour of the experiment, the content of D-xylose in the urine was significantly lower in experimental group 3 compared with experimental group $1\left(15.0 \%, \mathrm{p}_{1-3}<0.05\right)$. After 2 hours the result was similar. From the conditions of acute blood loss complicated by limb ischemia-reperfusion (experimental group 3), the indicator was $33.4 \%$ lower than in the group were only limb ischemia-reperfusion was simulated (experimental group 1) $(\mathrm{p}<0.05)$.

After 1 day, the content of D-xylose in the urine continued to remain statistically significantly lower in experimental group 3 compared with experimental groups 1 and 2 (respectively by $44.6 \%, \mathrm{p}_{1-3}<0.05$ and $33.0 \%, \mathrm{p}_{2-3}<0.05$ ). Starting from 7 days, a pattern was established, according to with increasing severity of the lesion decreased the content of Dxylose in the urine $\left(\mathrm{p}_{1-2}<0.05, \mathrm{p}_{1-3}<0.05, \mathrm{p}_{2-3}<0.05\right)$.

Under the influence of correction (Fig. 1) after 7 days of Carbacetam use, the content of D-xylose in the urine increased statistically significantly (by $18.6 \%, \mathrm{p}<0.05$ ) compared with the experimental group without correction. After 14 days of Carbacetam use compared with animals without correction, the figure became even higher - by $39.8 \%(\mathrm{p}<0.05)$. However, in this period the indicator did not reach the level of the control group and remained $21.9 \%$ lower $(\mathrm{p}<0.05)$.

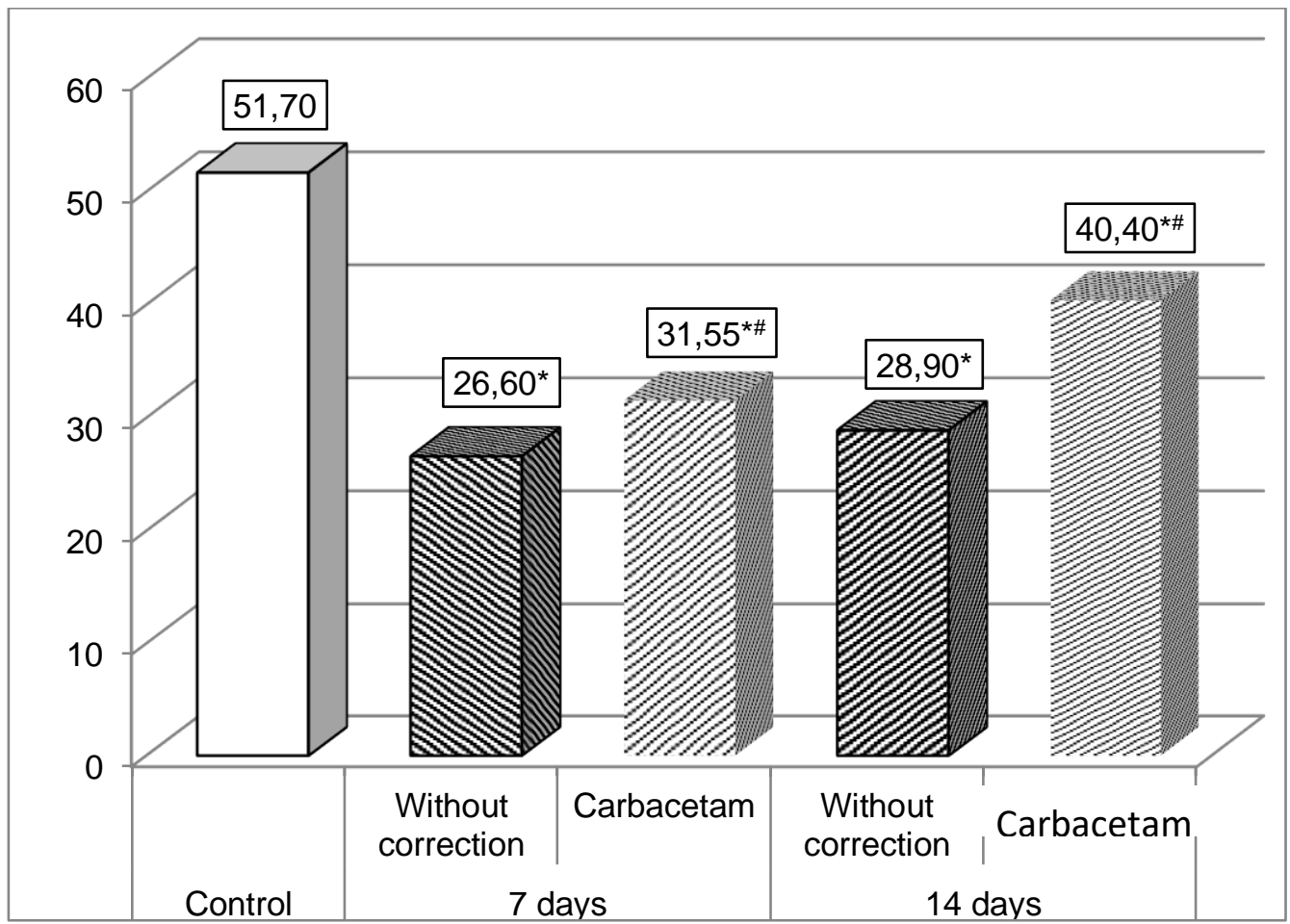

Figure 1 - The effect of Carbacetam on the content of D-xylose $\left(\mathrm{mg} \mathrm{ml}^{-1}\right)$ in the urine after acute blood loss complicated by ischemia-reperfusion of the limb. (Note. Here and in Fig. 2: * - differences to the control group are statistically significant, $\mathrm{p}<0.05$; ${ }^{\#}-$ differences to the group without correction are statistically significant, $\mathrm{p}<0.05$ ). 
The obtained results indicate that the simulation of ischemia-reperfusion of the limb, compared to the control, causes a decrease in the content of D-xylose in the urine only after 1 day of the reperfusion period. Also, acute blood loss accompanied of significant decrease in this indicator after 1 day. By the end of the experiment, the rate increases, but up to 14 days does not reach the level of control.

The combination of acute blood loss and ischemia-reperfusion of the limb causes a decrease in the content of D-xylose in the urine from 1 hour of the experiment, which reaches a minimum after 1 day and remains at the same level until 14 days. In these terms, the indicator is the lowest compared to other experimental groups. Therefore, with increasing severity of damage, the violation of absorption function of the small intestine occurs faster and more pronounced.

At the heart of the identified violations, obviously, nonspecific reaction of gastrointestinal tract to the centralization of blood circulation and hypoxemia that caused by acute blood loss, as well as the influence of endotoxins that enter the systemic bloodstream from the ischemic limb after reperfusion. All this creates the preconditions for the activation of prooxidant mechanisms in the wall of the small intestine, that was shown in our previous studies [15]. So, intensification of lipid peroxidation processes causes damage to cell membranes of structural components of the small intestinal wall, that leads to worsening of absorption function. We can assume, that under these conditions, other functions of the small intestine may suffer: motor, barrier, immune and others.

The use of Carbacetam for corrective purposes in rats with acute blood loss complicated by ischemia-reperfusion of the limb, compared with animals without correction significantly reduces the detected abnormalities after 7 days and more after 14 days of use. This positive action is obviously based on antioxidant, immunomodulatory, detoxifying, membrane-stabilizing and tissue-protective actions, as evidenced by the study of individual authors [12].

Thus, Carbacetam is accompanied by a systemic effect on the body and is able to significantly reduce the violation of the absorption function of the small intestine in conditions of acute blood loss complicated by ischemia-reperfusion of the limb, that requires further in-depth study.

Conclusions. 1. As a result of two-hour ischemia and reperfusion of the limb compared to the control in the small intestine after 1 day, significantly decreased of absorption function of the small intestine, that after 7 days normalizes and reaches the level of the control group. Under condition of acute blood loss, the studied indicator also decreases 
significantly after 1 day, increases up to 14 days, but does not reach the level of control. Complications of acute blood loss by ischemia-reperfusion of the limb causes a significant decrease of absorption function of the small intestine after 1 day of the experiment. The intensity of disorders is statistically significantly higher compared to other experimental groups.

2. The use of Carbacetam for 7-14 days in the reperfusion period for animals with acute blood loss complicated by ischemia-reperfusion of the limb, compared with animals without correction, causes a significant increase in the absorption function of the small intestine, indicating a protective effect of the drug in simulated pathology.

Prospects for further research. In the future, it is advisable to study the effect of acute blood loss and ischemia-reperfusion of the limb on other functions of the small intestine and evaluate the effectiveness of Carbacetam in these conditions.

\section{References:}

1. Bulger E. M., Snyder D., Schoelles K.et al. (2014) An evidence-based prehospital guideline for external hemorrhage control: American College of Surgeons Committee on Trauma. Prehospital Emergency Care.. no 18., pp.163-173.

2. Haida I. M., Badiuk M. I., Sushko Yu. I. (2018) Osoblyvosti struktury ta perebihu suchasnoi boiovoi travmy u viiskovosluzhbovtsiv Zbroinykh Syl Ukrainy. [Peculiarities of the structure and course of modern combat trauma in servicemen of the Armed Forces of Ukraine.] Pathologia. Vol. 15, no. 1., pp. 73 -76. [in Ukrainian].

3. Morsey H., Aslam M., Standfield N. (2003) Patients with critical ischemia of the lower limb are at risk of developing kidney dysfunction. Am J Surg.. Vol.185. pp. 360-363.

4. Su Q. S., Zhang J. G., Dong R. et al. (2010) Comparison of changes in markers of muscle damage induced by eccentric exercise and ischemia/reperfusion Scand J Med Sci Sports. Vol. 20, no 5. pp. 748-756.

5. Maksymyv R. V., Hudyma A. A., Sydorenko V. M. (2017) Dynamika balansu antyoksydantno-prooksydantnykh mekhanizmiv u vnutrishnikh orhanakh pid vplyvom arterialnoho dzhhuta i reperfuzii kintsivky. [Dynamic of balance of antioxidant-prooxidant mechanism in internal organs under the influence of the arterial tourniquet and limb reperfusion.] Shpytalna khirurhiia. Zhurnal imeni L. Ya. Kovalchuka. no 1., pp. 37-44. [in Ukrainian].

6. Horban I. I. (2020) Vplyv hostroi krovovtraty, uskladnenoi ishemiieiu-reperfuziieiu kintsivky, na antyoksydantno-prooksydantnyi balans pechinky ta yoho korektsiia karbatsetamom. [The effect of acute blood loss complicated by limb ischemia-reperfusion on 
the antioxidant-prooxidant balance of the liver and their correction by carbacetam.] Zdobutky klinichnoi i eksperymentalnoi medytsyny no 2., pp. 93-100. [in Ukrainian].

7. Shatskyi V. V., Hudyma A. A., Fedoniuk L. Ya. (2019) Dynamika antyoksydantnoprooksydantnoho balansu kirkovoho i mozkovoho shariv nyrky pislia hostroi krovovtraty, uskladnenoi ishemiieiu-reperfuziieiu kintsivky, ta yoho korektsiia karbatsetamom. [Dynamics of antioxidant-prooxidant balance of cortical and cerebral layers of the kidney after acute blood loss complicated by ischemia-reperfusion of the limb, and their correction by Carbacetam ] Zdobutky klinichnoi i eksperymentalnoi medytsyny.. no 4., pp. 144-153. [in Ukrainian].

8. Stakhiv O. V., Maksymyv R. V. (2020) Vplyv hostroi krovovtraty, uskladnenoi ishemiieiu-reperfuziieiu kintsivky, na aktyvnist protsesiv lipidnoi peroksydatsii u leheniakh ta yikh korektsiia karbatsetamom. [Influence of acute blood loss complicated by limb ischemiareperfusion on the activity of lipid peroxidation processes in lungs and their correction with carbacetam.] Visnyk medychnykh i biolohichnykh doslidzhen. no 3 (5)., pp. 108-114. [in Ukrainian].

9. Krutko E. N. (2008) Lechenie syndroma enteralnoi nedostatochnosti i postradavshykh s travmatycheskoi bolezniu. [Treatment of enteric insufficiency syndrome in victims with traumatic illness.] Kharkovskaia khyrurhycheskaia shkola. no 1 (28)., pp. 73 75. [in Russian].

10. Levchuk R. D., Deikalo I. M., Datsko T. V. (2014) Morfolohichni porushennia tonkoi kyshky yak peredumova rozvytku enteralnoi nedostatnosti $\mathrm{v}$ dynamitsi poiednanoi kranio-skeletnoi travmy. [Morphological damage to the small intestine like prerequisite for the development of enteral insufficiency in the dynamics of combined cranioskeletal trauma.] Materialy pidsumkovoi naukovo-praktychnoi konferentsii «Zdobutky klinichnoi $i$ eksperymentalnoi medytsyny», 21 travnia. Ternopil: Ukrmedknyha,. pp. 121. [in Ukrainian].

11. Andriushchenko V. P., Kunovskyi V. V., Malovanyi V. A. (2008) Syndrom enteralnoi nedostatnosti pry hostromu pankreatyti: patomorfolohichni zminy slyzovoi obolonky tonkoi kyshky ta shliakhy yikh medykamentoznoi korektsii. [Enteral insufficiency syndrome in acute pancreatitis: pathomorphological changes of the small intestinal mucosa and ways of their drug correction.] Kharkivska khirurhichna shkola.. no 2 (29)., pp. 72-75. [in Ukrainian].

12. Kozak D. V. (2014) Vplyv karbatsetamu na antyoksydantnyi-prooksydantnyi balans tkanyny sertsia, lehen i pechinky $\mathrm{v}$ dynamitsi politravmy. [Effect of carbacetam on 
antioxidant and prooxidant balance of heart, lungs and liver tissues in polytrauma dynamic]. Shpytalna khirurhiia. no 1 (65)., pp. 40-42. [in Ukrainian].

13. Markyna A. Y., Herashchenko Y. Y. (2013) Vlyianye enterosorbentov na vsasyvanye D-ksylozy $\mathrm{v}$ kyshechnyke laboratornykh zhyvontykh: fyzyko-khymycheskyi aspekt. [The influence of enterosorbents on the absorption of D-xylose in the intestines of laboratory animals: physicochemical aspect.] Poverkhnost..no. 5 (20). pp. 301-307. [in Russian].

14. Swinnen M. J. (1968) A colorimetric micromethod for the estimation of xylose in blood and urine. Biol. et gastroenterol.. no 2., pp. 194-200.

15. Strelbytska I., Hudyma A., Maksymiv R., Horban I. (2018) Dynamika antyoksydantno-prooksydantnoho balansu v stintsi tonkoi kyshky pid vplyvom arterialnoho dzhhuta i reperfuzii kintsivky. [Dynamics of antioxidant-prooxidant balance in the small intestine wall under the influence of arterial tourniquet and limb reperfusion] XXII Mizhnarodnyi medychnyi konhres studentiv ta molodykh vchenykh : materialy (23-25 kvitnia). Ternopil : Ukrmedknyha,. pp. 273-274. [in Ukrainian]. 